\title{
Contextualizing Statelessness in the Indian Legal Framework: Illegal Immigration in Assam
}

Anushka Sharma*

\section{Abstract}

With the publication of the National Register of Citizens (NRC) in Assam, the indispensable question regarding the legal status of individuals who would be excluded from the final version arises. This paper critically analyzes the legal framework that addresses and governs statelessness, by taking into consideration, both the domestic laws, and the international treaties which India is a party to, and argues that the contemporary legal system does not address the issue of statelessness effectively and requires an overhaul. The lack of a comprehensive legislative policy to address statelessness will prevent uniformity in the expulsion methods that is employed by the state. In the light of forced deportation and the subsequent expulsion, this paper highlights the significance of formulating a uniform policy that operates on established humanitarian principles that does not vary from one instance to another.

Keywords: Citizenship Act, 1945, Forced Deportation, International Conventions, National Register of Citizens, Statelessness

\section{Introduction}

A stateless person, as defined by the United Nations Convention Relating to the Status of Stateless Persons, 1954 is someone who is

* The West Bengal National Juridical Sciences, India; sharmaanushka@nujs.edu 
not considered a citizen by any Nation. ${ }^{1} \mathrm{~A}$ report of the United Nations High Commission for Refugees (UNHCR) points out that currently, there exists more than ten million stateless people in the world. ${ }^{2}$ The factors that contribute to statelessness include, but are not limited to displacement induced by conflict, exemplified by the widespread migration from Syria to various other countries such as Jordan and Egypt; development, which is illustrated by the Mexican migration to the United States and natural disasters coupled with environment factors; a prime example of which is the displacement induced by the Nepal earthquake. ${ }^{3}$ Other factors include discrimination based on ethnic or religious grounds and the emergence of new states or state succession. ${ }^{4}$ In the Indian context, factors such as decolonization and partition ${ }^{5}$, coupled with the existing conflict between erstwhile East and West Pakistan, have led to widespread migration from the neighboring states into our country, which, in certain instances have been rendered illegal, thereby, leading to statelessness. ${ }^{6}$

Statelessness effectuates gross vulnerability, as stateless individuals are not vested with rights that serve as a protective blanket against the miscreancy of either the state, or other private individuals, which invariably leads to them living in a perpetual state of a politico legal vacuum. Denied of the benefits relating to employment, education and health care, these persons are deprived of the protection of even the most basic human rights. ${ }^{7}$ This was brought out by Hannah Arendt in her seminal work, The Origins of Totalitarianism, written post World War II, when statelessness

${ }^{1}$ Convention Relating to the Status of Stateless Persons, Sep. 28, 1954, United Nations, Treaty Series, vol. 360, p.117, Article 1 Cl. 1.

2 United Nations High Commission for Refugees, Global Action Plan to End Statelessness, (Nov. 2014), http://www.unhcr.org/ stateless campaign 2014/Global-Action-Plan-eng.pdf.

${ }^{3}$ Andrew Scholten, International Law Aspects of Forced Deportations and Expulsions, (2016), https://www.aacademica.org/ andrew.scholten/ 9.pdf

4 Supra note 2.

${ }^{5}$ Asha Bangar, Statelessness in India ,Statelessness Working Paper Series, (June. 2017) http://www.institutesi.org/WP2017_02.pdf ${ }^{6}$ Id.

${ }^{7}$ Supra note 2. 
erupted on an unprecedented large scale.8She observed that the political status of a stateless person, is worse than that of a prisoner, for a stateless person loses the right to have rights. ${ }^{9} \mathrm{Apart}$ from having serious consequences on the stateless individuals, it has the potential to cause administrative difficulties in the host state and hamper economic development due to the presence of large scale unemployment, which will consequently overburden both the natural and economic resources.

This paper aims to understand statelessness in the context of illegal immigration in the state of Assam. It examines the existing domestic and international frameworks of law applicable to India and tries to understand the status of those who would be excluded from the final draft of the NRC. It explores the background of the Assam crisis, by analyzing two land mark judgments and discusses the Indian legislations that govern citizenship and examines the position of stateless people under them. It also throws light on the role played by the Supreme Court in addressing the issue and its attempts to resolve it. International Conventions to which India is a party, whose provisions address matters pertaining to nationality and statelessness, while primarily focusing on the roles played by the International Covenant on Civil and Political Rights (ICCPR) and Universal Declaration of Human Rights (UDHR) in situations of statelessness, is also examined in the due course of this paper. The possibility of forced deportation of those declared stateless, and their status in the light of the international provisions of law governing the same, also come under the purview of the paper. National and international principles governing statelessness are applied to the Assam crisis and the status of those who would be rendered stateless after the publication of the final NRC is enumerated. The author then applies and concludes by offering solutions to resolve this crisis.

${ }^{8}$ Asher Lazarus Hirsch and Nathan Bell, The Right to have Rights as a Right to Enter: Addressing a Lacuna in the International Refugee Protection Regime,18 Hum Rights Rev. 4, 419 (2017).

9 Sanjib Baruah, Stateless in Assam, The Indian Express, January 19, 2018, available at https://indianexpress.com/article/opinion/nationalregister-of-citizens-5030603/. 


\section{The Assam Crisis}

As a consequence of the scarcity of economic opportunities in the state of Bangladesh, and the increased competition as a result of population explosion, a number of people migrated and settled in the neighboring state of Assam.10The existing porous border between the two countries facilitated easy migration. The osmotic effect created due to the availability of better economic opportunities in India and the lack thereof in Bangladesh, further contributed to accelerated migration. ${ }^{11}$ The large scale migration inevitably resulted in an imbalance in the demographics in the state of Assam, reducing the indigenous people to a minority in certain districts. ${ }^{12}$ These factors coupled with the exhaustive use of the economic resources, culminated in a widespread protest by the All Assam Student Union, (AASU) demanding the identification and expulsion of illegal immigrants from the state. ${ }^{13}$ Consequently, the Assam Accord (The Accord) was signed between the protestors and the government, deciding March 24, 1971 as the cutoff date to determine citizenship of the immigrants. An amendment was subsequently made to the Citizenship Act, inculcating the Accord, stating that the immigrants who came to Assam before January 1, 1966 would be given Indian citizenship. ${ }^{14}$ The immigrants, who came on and after January 1, 1966 but before March 24, 1971 would be taken off the electoral rolls for the next ten years, after which their citizenship would be regularized. ${ }^{15}$ Lastly, the immigrants who came on or after March 25, 1971 would be identified and expelled from the country. ${ }^{16}$ It was further decided that the NRC would be updated to detect the illegal foreigners and expel them

${ }^{10}$ SarbanandaSonowal v. Union of India, (2005) 5 SCC 665, at 4.

11 id.

12 Id.at5.

$13 \mathrm{id}$.

$14 \S 6$ A, The Citizenship Act, 1955, Act No. 57 of 1955, Acts of Parliament, 1955 (India)

$15 \mathrm{id}$.

$16 \mathrm{id}$. 
accordingly. ${ }^{17}$ The Indian government also passed the Illegal Migrants (Determination by Tribunals) Act, 1983 (IMDT Act) to implement the Accord, by establishing tribunals to streamline the process of expulsion. ${ }^{18}$ Under the aforementioned Act, the burden of proof to prove the illegality of the immigrant lay on the state, rather than the individual in question. ${ }^{19}$

The constitutionality of the IMDT Act was challenged by one of the leaders of the Assam agitation, Sarbananda Sonowal, who contended that the provisions of the statute were highly in favor of illegal immigrants, and was in direct contravention of the purpose for which the Act was enacted, i.e. to expel illegal immigrants. ${ }^{20} \mathrm{He}$ further argued that the Act was in violation of Article 14 of the Indian Constitution, as it made an unreasonable distinction between the state of Assam (where the IMDT Act was applicable) and the rest of India (where the Foreigners Act was applicable and the burden of proof lay on the Illegal Immigrant). ${ }^{21}$ The court accepted his contentions and declared the IMDT Act unconstitutional, on the grounds of it being in violation of Article 14 and Article 355 of the Indian Constitution. It also held that the Act had established a high threshold of proof on the state, to disprove the citizenship of the illegal immigrants, which rather than accelerating the process of detection and deportation of the illegal immigrants, dreadfully slowed down the process and defeated the primary intention of the statute. ${ }^{22}$ The court observed that while section 9 of the Foreigners Act, casts the burden of proving citizenship on the alleged foreigner, there is no parimateria provision in the IMDT Act i.e. the Act is nebulous in relation to the

17 Sangeeta BarooahPisharoty, Why the NRC of 1951 is Being Updated as per the Assam Accord,TheWire,August 18, 2018, available at https:/ / thewire.in/rights/nrc-assam-accord-updating-residents

18 The Illegal Migrants (Determination by Tribunals) Act, 1983, Act No. 39 of 1983, Acts of Parliament, 1983 (India)

${ }^{19} \mathrm{Id}$.SarbanandaSonowal v. Union of India, (2005) 5 SCC 665, at 39.

${ }^{20}$ SarbanandaSonowal v. Union of India, (2005) 5 SCC 665

${ }^{21} \mathrm{Id}$.

22 Id Gautam Bhatia, The Constitutional Challenge to S. 6A of the Citizenship Act (Assam Accord): A Primer,(May. 7, 2017), available at https://indconlawphil.wordpress.com//?s=assam+accord\&search=G o. 
question of burden of proof.23In cases where a citizen reports the illegality of migration to the authorities, the provisions of the Act require the complaint to be accompanied with the exact date of immigration of the illegal immigrant into India. It further provides for criminal prosecution in case the contents of the complaint, given by a citizen, are found to be inaccurate. ${ }^{24}$ This will potentially discourage citizens, with significant information to come forward due to the fear of criminal prosecution associated with inaccuracy; invariably creating information asymmetry between the State and its people. Furthermore, the screening committee which was vested with the power to reject complaints regarding the determination of the status of illegal immigrants at the outset, with its orders being non-appealable, did not comprise of any judicial members and was run wholly by the executive, opening up the process to vulnerability and arbitrariness. ${ }^{25}$ Hence, the court observed that these provisions, not only place the illegal immigrants residing in Assam at an unfair advantage, vis-à-vis the illegal immigrants in the rest of the country, but also are in contradiction to the objective with which the IMDT Act was enacted.

The court also relied heavily on the concept of 'economic aggression,' that persisted in the state of Assam due to the unabated influx of migrants from Bangladesh. It held that the continued influx of immigrants into the state has enabled them to monopolize the majority of the cultivable land and the economic opportunities that were initially available to the original inhabitants. ${ }^{26}$ The resultant insurgency in the state and the consequent social unrest, severely hindered the economic growth and development of Assam ${ }^{27}$, bringing it under the ambit of Article 355 in the nature of external aggression. The existence of an external aggression mandates the Centre to protect the States against such insurgencies, by enacting appropriate laws. ${ }^{28}$

${ }^{23}$ SarbanandaSonowal v. Union of India, (2005) 5 SCC 665, at 27.

${ }^{24} \mathrm{Id}$. at 28.

25 Id. at 30 .

26 Id. at35.

27 Id.

${ }^{28}$ Sarbananda Sonowal v. Union of India, (2005) 5 SCC 665 
Subsequent to the delivery of the judgement, primarily due to the lack of a unified political will, the process of deportation of illegal immigrants was not accelerated. While some political parties intended on using this issue to win subsequent elections, the others found their vote banks in the immigrants. The utilization of the situation to further political propaganda, dissuaded the parties in power to actually deport the illegal immigrants. Hence, another writ petition was filed before the Supreme Court in the case of Assam Sanmilita Mahasangha v. Union of India ${ }^{29}$ (Assam Sanmilita) in 2012, pleading with the court to ensure the speedy deportation of illegal immigrants and a variety of related reliefs. It was through this judgement, that a two judge bench comprising of Justice Nariman and Justice Gogoi supervised the process of deportation and issued directives regarding the updating of the NRC. ${ }^{30}$ Justice Nariman, in the course of rendering his judgement, framed 13 questions of law, which were then subsequently transferred to a five judge constitutional bench, for its consideration and decision. The question of the validity of section 6A of the Citizenship Act was included in the list of questions. ${ }^{31}$ There are, however, certain pertinent legal issues associated with it. While the aforementioned division bench of the Court referred the question of the validity of section 6A of the Citizenship Act to a larger constitutional bench for its decision, it absurdly proceeded to issue far reaching directions premised on the validity of the aforementioned section, ${ }^{32}$ further exposing it to ambiguous interpretations and suggestive irrationality.

It is observed that while the court emphasized on the detection of the foreigners, it entirely avoided the relevant discussion on the fate of the persons who will end up being excluded from the NRC. The lack of discussion on the resulting statelessness will irrevocably leave a gaping hole, as its far reaching implications, due to lack of proper debate and consideration, will not be appropriately realized. The lack of foresight in the matter, will

\footnotetext{
${ }^{29}$ Assam SanmilitaMahasangha v. Union of India, (2015) 3 SCC 1.

$30 \mathrm{Id}$.

$31 \mathrm{Id}$.

${ }^{32}$ Supra note 3.
} 
inevitably lead to the formulation of a policy that is non-exhaustive and ineffective in dealing the resultant circumstances.

The court however, directed the Government of India to enter into necessary discussions, to minimize the resultant statelessness, with the Government of Bangladesh in the case of Assam Sanmilita Mahasangha $v$. Union of India. ${ }^{33}$ However, there has been no evidence of any on-record discussions between the two countries on the issue. ${ }^{34}$ There is an absence of agreement between India and Bangladesh in which the latter has agreed to take back the persons who will be declared as illegal immigrants under the IMDT Act. A statement given by Bangladesh's Information Minister, denying unauthorized immigration from Bangladesh to India, and the lack of effective measures taken by the Indian government to combat the increasing immigration in the last thirty year reveals their political stance on the matter. ${ }^{35}$

In the absence of a legally established procedure, there are only two alternatives available to the state, to deal with the persons declared as illegal immigrants - one being forced deportation, and the other being, confinement of the immigrants in detention centers. ${ }^{36}$ The lack of economic feasibility to construct detention centers with a capacity to detain over four million people for the near future, makes forced deportation the more viable option for the State, which will invariably render these people stateless, and leave them without any rights or remedies. The lack of a definite legal framework to sufficiently address the issue of statelessness, due to the failure on the part of both the Judiciary and the Legislature, has led to various human rights organizations across the world, such as Amnesty International and Human Rights Watch, to express concern over the impending crisis. ${ }^{37}$

33 Assam Sanmilita Mahasangha v. Union of India, (2015) 3 SCC 1

${ }^{34}$ Baruah, supra note 7 .

${ }^{35} \mathrm{Id}$.

${ }^{36}$ Alok Prasanna Kumar, To What End This Exercise, The Hindu, August 2, 2018, available at https://www.thehindu.com/todays-paper/tpopinion/to-what-end-this-exercise/article24576858.ece.

37 Amnesty International India, India: Assam's Citizen Identification can Exclude 4 Million People Ensure Rights, Non discrimination for all Residents(July.31, 2018), available at https://amnesty.org.in/news- 


\section{Domestic Legal Framework}

Despite having a history of harboring refugees from various countries and having witnessed large scale migration, India does not have a comprehensive and codified legislation that deals with statelessness. Therefore, the position of the illegal immigrants in our country and specifically in Assam, can be discerned by studyingthe existing laws that regulate citizenship in India, which primarily comprises of the Foreigners Act, 1946, Citizenship Act, 1945 and Article 5 of the Indian Constitution.

As per Article 5, a person domiciled in India at the time of commencement of the Constitution, who was, or either of whose parents was born in India, or who was an ordinary resident of India five years prior to the commencement of the constitution, is deemed to be an Indian citizen. ${ }^{38}$ This provision, read with the Citizenship Act, 1945, provides for the acquisition of citizenship by birth, descent, naturalization, registration or incorporation of a new territory. ${ }^{39}$ It occurs, in the context of migration, an immigrant can only acquire citizenship through naturalization or registration. ${ }^{40}$ However, under sections 5 and 6 of the Citizenship Act, illegal immigrants can neither acquire citizenship by naturalization or by registration, as the precondition to avail a remedy under these provisions is to be a legal immigrant. ${ }^{41}$ Thus, these provisions have the potential to render thousands of families stateless, despite them being residents of India for generations, as is the case with some families in Assam. ${ }^{42}$

update/india-assams-citizen-identification-can-exclude-4-millionpeople-ensure-rights-nondiscrimination-for-all-residents/.

38 Indian Const., Art. 5

39 The Citizenship Act, 1950.Deepika Prakash and Maanvi Tiku, Report on India and the Challenge of Statelessness: A Review of the Legal Framework Relating to Nationality, 23 (2014).

40 The Citizenship Act, 1955, Act No. 57 of 1955, Acts of Parliament, 1955 (India)

$41 \S 5 \& 6$, The Citizenship Act, 1955, Act No. 57 of 1955, Acts of Parliament, 1955 (India)

42 Harsh Mander, The dark side of humanity and legality; A glimpse inside Assam's detention centres for 'foreigners,' The Scroll, June 26, 
The standard to provide citizenship by birth to children, has also been made more stringent over the years, by the government. Under section 3 of the Citizenship Act, children born before July 1, 1987, acquire citizenship at birth, irrespective of the nationality of their parents. ${ }^{43}$ Those born on and after July 1, 1987 but before December 3, 2004 would be given citizenship at birth, if either of their parents is Indian. ${ }^{44}$ But by virtue of the amendment to the aforementioned section, the children born after December 3, 2004, of which if one of the parents is an Indian citizen and the other an illegal immigrant, now stand disqualified from being granted citizenship by birth. ${ }^{45}$ The amendment points towards a gradual shift of the Indian citizenship policy from being jus soli (by soil) oriented, to being jus sanguinis (by blood) oriented, as now the mere birth of a child on the Indian territory is insufficient for him to get citizenship. This shift has unfavorably impacted the interests of such children, as they, by virtue of having an illegal immigrant as a parent, become ineligible to obtain citizenship by birth. This state of ineligibility to acquire a citizenship status cannot be altered retrospectively, thereby, unjustly condemning these children to a life in a politico-legal vacuum.

The introduction of the Citizenship (Amendment) Bill, 2016 is vested with the potential to impact the lives of the alleged foreigners positively. The bill proposes to relax the provisions for granting citizenship to illegal immigrants. It proposes two major amendments - firstly, people belonging to the Hindu, Sikh, Jain, Buddhist, Christian and Parsi communities from Afghanistan, Bangladesh and Pakistan would not be considered illegal immigrants for the purpose of the Act, thereby making them eligible to apply for citizenship. ${ }^{46}$ Secondly, it reduces the period of naturalization to acquire citizenship for the members of these

2018, available at https://scroll.in/article/883936/assam-citizensregister-detention-centres-for-foreigners-offer-a-glimpse-of-the-

looming-tragedy.

${ }^{43}$ §3, The Citizenship Act, 1955, Act No. 57 of 1955, Acts of Parliament, 1955 (India)

44 Id.

45 The Citizenship (Amendment) Act, 2003, Cl. 3(c)(ii).

${ }^{46}$ The Citizenship (Amendment) Bill, 2016, 172 of 2016, Cl. 2. 
communities from eleven years to six years (excluding the period of twelve months preceding the application). ${ }^{47}$ The provision does not provide for deemed citizenship to the people of these communities, i.e. it does not automatically confer citizenship upon the completion of the naturalization period, but simply makes them eligible to apply for citizenship. ${ }^{48}$ However, this amendment does not include the members of the Muslim community, thereby, making it blatantly discriminative in nature. There is a gross lack of secular approach, as the Bill, while striving to protect members belonging to other communities from statelessness, refuses to recognize and minimize the impact on the Muslim community.

The Indian courts have failed to address, let alone deal with the issue of statelessness which is evident from the non-existence of a definition for the term. However, there has been recognition of statelessness which has found mention in various cases regarding citizenship. In the case of State of Arunachal Pradesh v. Khudiram Chakma, ${ }^{49}$ the Supreme Court while deciding the fate of the Chakmas, who were primarily refugees, held that the government cannot send them back because they face a threat of torture and persecution upon return to their own country, i.e. the doctrine of non-refoulement will invariably apply in situations involving refugees. Therefore, sending them back would be in violation of Article 21 of the constitution, which is impermissible as even noncitizens enjoy the protection of article 21. However, the same rationale cannot be extended to the situation of illegal immigrants in Assam for two reasons, the first being that they are not refugees but are rather illegal immigrants, who have faced widespread opposition and protest from the locals against their presence. A reading of the judgements of the Supreme Court in the cases

\footnotetext{
${ }^{47}$ Id. at Cl. 4.

48 Raghav Katyal, Citizenship (Amendment) Bill: A positive step but BJP government must justify religion-based provisions in proposal, The Firtstpost, January 10, 2018, available at https://www.firstpost.com/ india/ citizenship-amendment-bill-a-positive-step-but-bjp-govt-mustjustify-religion-based-provisions-in-proposal-4296621.html.

49 State of Arunachal Pradesh v. Khudiram Chakma AIR 1994 1461, DeepikaPrakash and MaanviTiku, Report on India and the Challenge of Statelessness: A Review of the Legal Framework Relating to Nationality, 64, 65 (2014)
} 
Sarbananda Sonowal and Assam Sanmilita indicates that the Supreme Court does not have an inclusive attitude towards them, which is made evident in its consideration of the immigrants as a threat to the national and the economic interests of the country. ${ }^{50}$ Secondly, the reason behind the invocation of Article 21 by the court, in the case of the Chakmas, was due to the ever present threat of persecution upon return to their own country. The court recognized the inherent difference that exists between refugees and illegal immigrants, when they refused to extend the protection of Article 21 while dealing with the expulsion of these immigrants. Hence, while the protection of Article 21 will continue to extend to them with respect to the other facets, for as long as they reside within the territorial boundaries of India, it cannot be utilized by the illegal immigrants to escape expulsion.

\section{International Conventions and the Indian Legal Scenario}

The two primary documents governing statelessness at the international level, are the UN Convention Relating to the Status of Stateless Persons, 1954 and The Convention on the Reduction of Statelessness, 1961.51The 1954 convention defines the term statelessness, but does not provide for a mechanism that can be stringently employed to determine statelessness. The formulation of a mechanism is thus, left to the discretion of the states. ${ }^{2}$ Notably, India has not signed/ratified/acceded/adopted either of these Conventions. ${ }^{53}$ However, conventions such as the UDHR and the

50 Sarbananda Sonowal v. Union of India (2005) 5 SCC 665.Assam Sanmilita Mahasangha v. Union of India, (2015) 3 SCC 1.

51 Convention Relating to the Status of Stateless Persons, September 28, 1954, United Nations, Treaty Series, vol. 360, p.117. Convention on the Reduction of Statelessness, August 30, 1961, United Nations Treaty Series, vol. 989, p. 175.

52 European Network on Statelessness, Statelessness: Determination and the Protection Status of Stateless Persons, available at http:/ / www.refworld.org/pdfid/53162a2f4.pdf.

53 Sabysachi Basu Ray Chaudhury \& Ranabir Samaddar, The Rohingya in South Asia, 76 (2018).Shuvro Prosun Sarkar, Reducing Statelessness: A New Call for India, The Rohingya in South Asia 172-189 (2018). 
ICCPR, to which India is a party, contain provisions that will be attracted in the event of statelessness.

The UDHR is considered to be the cornerstone of International Humanitarian Law and was adopted by the UN General Assembly on December 10, 1948, in Paris. ${ }^{54}$ It delineates certain fundamental human rights which are to be protected universally and is now a part of customary international law. ${ }^{55}$ Article 15 of the Declaration provides for the right to nationality to 'everyone,' the corollary of which imposes an obligation on the nation-states to ensure that no person is rendered stateless. ${ }^{56}$ However, it is not succinct in bringing out the parties against whom one can enforce the right to nationality i.e. it does not impose a definitive obligation on the home country or the host country and leaves the situation to dictate upon whom the responsibility rests. This ambiguity will facilitate nation-states to evade the responsibility of either hosting or readmitting stateless individuals.

The convention also provides a safeguard to the stateless people under Article 2, which states that no distinction can be made between people on the basis of their national origin, for the purposes of the convention. ${ }^{57}$ This article is a significant provision as it mandates the government to provide the stateless people with basic human rights as enshrined in the UDHR. This can be contrasted with the prevalent realities in the state of Assam, where a study conducted by the National Human Rights Commission has pointed towards the violation of basic human rights of the illegal immigrants who have been kept in the detention centers. ${ }^{58}$ There

${ }^{54}$ United Nations, Universal Declaration of Human Rights, available athttp:/ / www.un.org/en/universal-declaration-human-rights/

55 Deepika Prakash and Maanvi Tiku, Report on India and the Challenge of Statelessness: A Review of the Legal Framework Relating to Nationality, 11, 12 (2014)

${ }^{56}$ Universal Declaration of Human Rights, G.A. Res. 217A, (December 12, 1948) Article 15.

${ }^{57}$ Id., Article 2.

58 National Human Rights Commission, Report on NHRC Mission to Assam's Detention Centers from 22 to 24 January, 2018, (Mar.3,2018), available 
exist other provisions of the Covenant, which operate to confer on the persons covered under it, an equal protection of the law ${ }^{59}$ along with the right to protection against torture and inhuman treatment. It further provides for punishments in cases of infringement including unlawful confinement in detention centers. 60

Another pertinent convention regarding the protection of human rights is the ICCPR, which was acceded to by India on April 10, 1979.61 The rights under the Covenant are available to all people irrespective of the status of their nationality, like the UDHR. ${ }^{62}$ Article 24 of the Covenant aims to protect the rights of a child, and vests in him the right to acquire a nationality. ${ }^{63}$ Section 3 of the Citizenship Act, which denies the right to a child to get citizenship by birth, in case either of his parents, is an illegal immigrant, is in direct contravention to this provision. ${ }^{64}$ Further, the section also violates Article 7 of the United Nations Convention on the Rights of the Child (CRC) which India has acceded to, as the Convention mandates the state to provide nationality to the child immediately post birth. 65 The UNHCR, in its ten point action plan to end statelessness across the world by 2024, has also remarked that the states must endeavor to grant nationality to those children who cannot acquire it from any other nation. ${ }^{66}$ Hence, the Indian

athttps:/ / drive.google.com/file/d/1skGrqF6L8XnW8nsYbw2oruAi5y KsuxUx/view.

59 Universal Declaration of Human Rights, G.A. Res. 217A, (December 12, 1948) Article 7.

${ }^{60}$ Id., Article 5.

${ }^{61}$ National Human Rights Commission, Core International Human Rights

Treaties, Optional Protocols \& Core ILO Conventions Ratified by India, available at http://www.nhrc.nic.in/ documents/ india_ratification_ status.pdf.

62 International Covenant on Civil and Political Rights, December 16, 1966,

United Nations, Treaty Series, vol. 999, p. 171, Article 2.

${ }^{63}$ Id., Article 24.

64 §3, The Citizenship Act, 1955,Act No. 57 of 1955, Acts of Parliament, 1955 (India)

65 Convention on the Rights of the Child, United Nations, Treaty Series, vol. 1577, p. 3, Article 7.

${ }^{66}$ Supra note 2. 
citizenship policy runs contrary to multiple International provisions.

\section{Legal Implications of Forced Deportation}

The irrepressible questions regarding the forced deportation of illegal immigrants and whether it aligns with the International Legal Framework that India has ratified, will invariably arise after the publication of the NRC. The need to speedily address these difficult questions and seek comprehensive solutions, which are in line with conventions and treaties, is pressing and indispensable.

The regulatory framework regarding deportation under the International law is not governed by any singular legislation that is exclusively dedicated to deal with the issue. A question that then arises in this respect is, whether a state has a right to forcefully expel or deport the illegal immigrants who are consequently rendered stateless? Can it exercise its sovereignty in denying these people their human rights? Does the procedure of deportation need to be in consonance with the basic principles of human rights or can the state employ any means that it deems fit?

The CCPR General Comment 15 states that, it is a matter of discretion of the state in matters regarding the admission and residence of an alien in its territory ${ }^{67}$ However, the alien will enjoy the protection of certain rights under the covenant in relation to the entry or residence, such as the right against being subjected to inhuman treatment. ${ }^{68} \mathrm{~A}$ discussion paper of the office of the United Nations High Commissioner for Human Rights (OHCHR) on this issue, ${ }^{69}$ mentions that there are three kinds of protections against expulsion that are available to foreigners. They include(i) substantive protection against expulsion if there is a threat of grave human rights violations on return, (ii) procedural measures

${ }^{67}$ United Nations Human Rights Committee, CCPR General Comment No. 15: The Position of Aliens Under the Covenant, April 11, 1986, available at http://www.refworld.org/pdfid/45139acfc.pdf. ${ }^{68} \mathrm{Id}$.

${ }^{69} \mathrm{OHCHR}$ discussion paper, Expulsion of Aliens in International Human Rights Law, (September, 2006). 
governing deportation and (iii) protection regarding the methods of expulsion.

The first ground of protection available to the aliens (which includes stateless people) is given under Article 7 of the CCPR, which has been read to include the prohibition of the expulsion of aliens, if there exists a substantial danger of torture upon return. ${ }^{70}$ Additionally, in the General Comment 31/80, it has been categorically stated that the obligation of the state to ensure that the rights under the Covenant are available to all people in its territory under Article 2 of the ICCPR, entails that a person in danger of facing human rights violations on return, should be allowed to remain in its territory. ${ }^{71}$ In the situation concerning the immigrants in Assam, there exists an absence of a threat of persecution upon their return as opposed to refugees, and hence, the doctrine of nonrefoulement will fail to apply in this case.

One of the procedural safeguards that is available to a stateless person under Article 13 of the ICCPR, mandates a due process to be followed while expelling an alien who is in line with the principles of natural justice. This process automatically involves granting the alien a chance to represent himself, except in cases where the expulsion is on the basis of maintaining national security. ${ }^{72}$ However, this protection is only available to the aliens who are in the territory lawfully and would therefore not extend to illegal immigrants. ${ }^{73}$

70 United Nations Human Rights Committee, CCPR General comment No. 20: Article 7 (Prohibition of Torture or Other Cruel, Inhuman or Degrading Treatment or Punishment), (Mar. 10, 1992), available at http://www.refworld.org/docid/453883fb0.html. OHCHR discussion paper, Expulsion of Aliens in International Human Rights Law, (September, 2006).

71 United Nations Human Rights Committee, General comment no.31[80 ], The nature of the general legal obligation imposed on States Parties to the Covenant, (May. 26, 2004), available at http:/ / www.refworld.org/ docid/478b26ae2.html

72 International Covenant on Civil and Political Rights, December 16, 1966, United Nations, Treaty Series, vol. 999, p. 171, Article 13.

$73 \mathrm{OHCHR}$ discussion paper, Expulsion of Aliens in International Human Rights Law, (September, 2006). 
The third ground of protection regarding the limitations placed on the method of deportation prohibits mass expulsions by the state and requires that each person's case must be scrutinized on an individual basis. ${ }^{74}$ The government, in the context of Assam, is meticulously scrutinizing each individual application. Further, it is required as a general principle, over and above these provisions, that the method of expulsion should not subject the person to degrading, cruel or inhuman treatment. ${ }^{75}$

\section{The Status of the Immigrants in Assam}

An overview of the law governing citizenship in India and the International Conventions and Covenants that bind it, suggest that even though there is no concrete legislation that governs statelessness, there are multiple provisions under the Indian legal framework (inclusive of both national and international legislations) that will apply in the situation at hand. However, there is a significant absence of legislations, which address and elucidate the status of the people who will be rendered stateless after the publication of the final draft of the NRC. The non-ratification of the two primary instruments that govern statelessness in the international level by India, substantially complicates matters.

The domestic laws that govern citizenship have been made increasingly stringent over the years and exclude illegal immigrants from acquiring citizenship, by registration or by naturalization. The judgements penned by the Apex court in the cases relating to illegal immigration in Assam also indicate that the Court does not have a particularly humanitarian approach towards the matter. Rather, the court has taken notice of the economic difficulties stemming out of the migration and has been proexpulsion throughout.76Their intervention is limited to ensuring that the decision of expulsion of these suspected illegal migrants is made in accordance with the existing legal provisions.

74 Id. at 15.

${ }^{75} \mathrm{Id}$. at 17.

76 SarbanandaSonowal v. Union of India (2005) 5 SCC 665. Assam SanmilitaMahasangha v. Union of India, (2015) 3 SCC 1. 
The provisions that prohibit forced deportation also ultimately vest the right of expulsion of aliens with the state as its sovereign prerogative. The only exception that seems to have been carved out in this area is when the person faces a threat of persecution or grave human rights violations on return, which is not the case with these people. It seems to be highly unlikely that the government of Bangladesh, which is already struggling with the problems of population explosion and the rehabilitation of the rohingya refugees, would be willing to take back these people as its own nationals. ${ }^{77}$ In such a situation, these people would be forced to either live in India as stateless people, who will merely have the protection of Article 21 or they would be subjected to forcible deportation, as the principles of non-refoulement are not applicable in the given situation. The condition of these stateless individuals, subsequent to the non-inclusion in the NRC would be worse than that of the refugees, for the refugees can either avail the principles of non-refoulement to stay in the host country or can force their home country to readmit them under International law.

There seem be two possible solutions to this crisis, the first being the Bangladeshi government absorbing all the illegal immigrants into their country, which as discussed above is politically unlikely and economically unsound from their perspective. The second can be to grant Indian citizenship to all illegal immigrants, which appears more feasible, as even at present it is our country that is providing them with economic and social shelter. Additionally, it would be in furtherance of the humanitarian responsibility of the Indian state. The resentment amongst the local people upon granting citizenship to the illegal immigrants could lead to severe backlash, causing political and economic instability in the region. Hence, the government must initiate a conciliation process with the local leaders of the Assam movement which will facilitate a compromise that would include both granting the illegal immigrants the right to reside in the area and not give them political rights for a period of time, as was also done in the Assam Accord. Alternatively, a treaty can be negotiated with the government of Bangladesh pursuant to which the immigrants can

77 Supra note 9. 
be sent back in phases which would not burden the economy of Bangladesh. The Indian government can further promise economic benefits as incentives to formulate a treaty to provide for a uniform due process that would be followed by both governments to combat statelessness. It is imperative that political leaders take the initiative to resolve the crisis, as political will is of utmost importance in finding a solution. The governments as well as the citizens of both the countries must display the willingness to resolve the issue amicably, in an expedient manner.

\section{Conclusion}

Dr. Ambedkar once remarked that Article 5, which dealt with citizenship, was the most cumbersome provision to draft in the entire constitution, as the world was going to scrutinize the Indian citizenship policy based on it. ${ }^{78}$ Now, as we steer closer towards the publication of the final draft of the National Register of Citizens (NRC) in Assam, the eyes of the world would again be on the Indian government's policy to deal with this complex issue of citizenship, which could turn around four million people, stateless. Since, the laws as currently applicable in India, do not provide sufficient protection to stateless people, it becomes necessary for the government to adopt a humanitarian approach towards these people and give due consideration to the vulnerable sections of the society such as widows, who have no proof of residence, post marriage or children whose parents are deceased.

The approach of the Supreme Court in dealing with the issue of statelessness has not instilled hope in the stateless population of the country; with the court largely favouring the government in its design, to deport those who have been declared as illegal immigrants. This is made evident by the increased inculcation of stringent methods to establish the citizenship of an individual. There being no provision to accord citizenship to illegal immigrants by naturalization, the statutory framework governing citizenship in India also fails to address this problem. The non-ratification of the International Conventions governing statelessness by India, further exacerbates the situation and cements the position of stateless

78 Katyal, supra note 35. 
people in a state of uncertainty and insecurity. There is a need for the Indian government to either ratify the International Conventions that govern statelessness and consequently formulate a legislative policy in accordance with it or to deal with statelessness effectively by amending the current laws by reducing the scope of arbitrariness that exists regarding the status of these people.

In the light of the socio-political framework as it stands currently, the possible options to resolve this crisis seem to be either by granting citizenship to the illegal immigrants or to negotiate a treaty with the government of Bangladesh, pursuant to which the latter agrees to take back these citizens, both of which seem unlikely at this stage, as has been discussed previously in the paper. Hence, it is imperative to find a legal solution for this impending crisis so as to ensure that there are no people left without the 'right to have rights', at the end of this exercise. 